\title{
Evaluating changes in ranch management practices through extension education
}

\author{
REBECCA T. RICHARDS AND MELVIN R. GEORGE
}

\begin{abstract}
Authors are assistant professor with the Department of Sociology, University of Montana, Missoula, Mont. 59812 and range extension specialist with the Department of Agronomy and Range Science, University of California, Davis, Calif. 95616.
\end{abstract}

\begin{abstract}
Since 1988, University of California Cooperative Extension short courses have been offered to 362 California ranchers and interested participants. The purpose was to assist private rangeland owners and managers in planning ranch goals, monitoring ranch operations, and establishing economically feasible and ecologically sustainable grazing management systems. In 1994, an evaluation study of the short courses was conducted to determine if the rancher participants had initiated successful improvements in their ranching and grazing management. A survey questionnaire mailed to all short course participants had a rancher response rate of $49 \%$. Results of the survey indicate that over three-quarters of the ranchers had family operations, most of which were cow-calf operations. Almost $40 \%$ of the ranchers earned more than half of their income directly from their ranching operation. As a result of having taken the short courses, ranchers reported that they had improved or protected $14 \%$ of the rangeland which they owned or leased. Over half said that they had increased their ranching profits. A majority of respondents had implemented at least one ranching practice presented in the short course. These changes appear to be motivated from ranchers' needs to increase on-ranch profits through enterprise diversification, to cope with regulatory constraints, and to improve land management for future generations on a family ranch.
\end{abstract}

Key Words: ranch management, grazing management, extension education, technology transfer

Just over half the land in California, approximately 20.4 million hectares, is privately awned. More than one-third of these private lands, or nearly 7.2 million hectares, are grazed by livestock (Ewing et al. 1988). At the same time, California's urban population is rapidly expanding. As a result, California ranchers face greater economic difficulties in maintaining viable ranching operations and more complex

Research was funded by the Renewable Resources Extension Act (RREA) through the Division of Agricultural and Natural Resources, University of California. An early draft of this paper was presented at the Fifth International Symposium on Society and Resource Management in Fort Collins. We would like to thank Grry Frasier, John Mitchell, Greg Greenwood, and 2 anonymous reviewers for their helpful comments on earlier drafts

Manuscript accepted 8 Apr. 1995. social challenges in managing their rangeland resources.

To address ranchers' economic and management needs, 252 total hours of ranch planning and grazing management short courses have been offered to over 900 participants in 16 California counties since 1988 . The short courses have instructed participants in ranch goal identification and review, ranch enterprise management, ranching practices and productivity, and grazing management.

The ranch planning short course was designed to teach participants how to plan and implement integrated ranch management and controlled grazing. A hypothetical 300-cow ranch enterprise and its associated land resources were used to teach ranch planning through the development of goals, ranch resource inventory, and enterprise analysis (George 1990). As a follow-up course to ranch planning, the grazing management short course was developed to focus on the principles of controlled grazing (George and Bell 1990). The grazing management course was designed to aid ranchers in deciding whether and how to use intensive grazing management.

In September 1993, an evaluation study of the ranch planning and grazing management short courses was developed. Since no baseline data had been collected on the existing ranch and grazing management practices of the participants, the study could not evaluate prior conditions. The purpose of an evaluation study is not to test hypotheses but to identify the perceptible impacts and judgmental criteria of a program's worth (Burstein and Freeman 1985). The objective of our study was to assess the degree to which short course participation had either reinforced or introduced and promoted effective ranch and grazing management practices.

\section{Methods}

Our study was based on a mail survey questionnaire designed and administered following the Total Design Method (Dillman 1978). Registration lists for the ranch and grazing management short courses were obtained from each of the county farm advisors who had helped sponsor the ranch resource and grazing management short courses since 1988. These lists were compiled into a master address list of 362 individual, short course registrants. The mail survey questionnaire was mailed in January 1994 with a 
second mailing to nonrespondents in February 1994. Of the 362 questionnaires initially mailed, 35 were returned as undeliverable and 38 were returned from registrants who were not ranchers. Of the remaining 289 questionnaires, 142 were completed and returned from ranchers who had taken at least one short course. The overall rancher response rate was $49 \%$. Because short course enrollment data did not include rancher telephone numbers, we were unable to contact nonrespondents to determine whether participants responding to the survey were significantly different from those not responding. After the completed questionnaires were returned, we coded quantitative responses, obtained descriptive statistics, and compiled qualitative comments and characterized trends in respondent answers.

\section{Results}

\section{Ranch Operations}

Almost the same proportion of respondents had taken at least 1 ranch planning course $(66 \%)$ as 1 grazing management course $(63 \%)$. Some $(38 \%)$ of the participants had taken the short courses with someone else, primarily a spouse $(52 \%)$ or relative $(43 \%)$.

A minority (39\%) of the respondents said that at least onehalf of their annual gross, household income came directly from their ranching operation. The most common main ranch operation reported in the survey was cow-calf (69\%). Multiple or other operations (24\%) followed, including rock quarries, emus, vineyards, row crops, orchards, horses, sheep, hay, firewood, and ecotourism. Over one-quarter (26\%) of the respondents had added a ranch operation since taking the short course. The most frequently added operation was cowcalf $(6 \%)$. A diverse group (20\%) of other added operations followed, including flowers, vineyards, emus, and row crops. A smaller number (15\%) of the participants had dropped a ranch operation from their enterprise. The most frequently dropped operation was hay ( $4 \%$ ) followed by sheep (3\%). The majority $(77 \%)$ of respondents reported that their ranches were family or individual operations while a smaller proportion $(18 \%)$ said their ranches were family or non-family partnerships. Very few $(5 \%)$ reported that their ranches were corporations or other nonfamily operations.

\section{Rancher Characteristics}

Respondents were generally men $(77 \%)$ in late middle-age ( mean $=49$ years; median $=48$ years) who owned or leased more land (mean $=\$ 76$ hectares; median $=230$ hectares) than the average California farm or ranch (mean $=147$ hectares) (U.S. Bureau of the Census, 1987). In all, short course participants responding to the survey owned or leased a total of 114,330 hectares or approximately $2 \%$ of California's 7.2 million acres of private rangeland. When asked how satisfied they were with their ranch on a 1 to 5 scale (where 1 was Very Satisfied and 5 was Very Dissatisfied), respondents were generally satisfied (mean = 2.3 ; median $=2.0$ ).

Of the responding participants, more than half $(58 \%)$ said that they wanted to maintain their ranch as a working ranch. More than a third $(37 \%)$ reported that they wanted to diversify and maintain the ranch as a working ranch. Only $4 \%$ of the ranchers in the survey said that they wanted to sell the ranch for development, and less than $1 \%$ said that they wanted to sell the ranch for land conservation. However, significant numbers of the survey respondents said that their ranches were enrolled in some form of land conservation program. Over half $(55 \%)$ said their ranch was in California's agricultural protection program known as the Williamson Act, California's major program for the protection of agricultural land (Sokolow 1989). Another $23 \%$ of the respondents were participating in a variety of other agricultural programs including the Agricultural Conservation Program, Long-Term Agreements, Vegetation Management Plans, and Coordinated Resource Management Plans. Less than one-quarter (23\%) of the ranchers reported no participation in any agricultural conservation program.

\section{Ranch Management}

The great majority of the respondents said that they as a result of the short courses, they had begun setting ( $82 \%)$ and reviewing $(85 \%)$ goals for their ranches. Slightly more than half said they had changed goals for their ranch (56\%)and had increased their ranching profits (53\%). Almost half (49\%) said that the short courses had prompted them to hold periodic ranch meetings. About half $(47 \%)$ also said that the short courses had helped them reduce ranching costs. A quarter of the respondents $(25 \%)$ reported that they had changed their marketing practices.

Respondents reported that, as a result of having taken the short courses, they had improved or protected (mean $=109$ hectares) a total of 15,746 hectares or $14 \%$ of the total ranch acreage represented in the survey. The majority of ranchers responding to the survey had implemented at least one ranching practice presented in the short course (mean $=2.9$ practices). The most common ranching practice implemented was fence installation $(63 \%)$, primarily with smooth wire and/or portable electric fencing. Fence installation was followed by water development ( $47 \%$ ), especially water troughs. Seeding range or irrigated pastures $(43 \%)$ was the third most common practice, most frequently with perennial grasses. A fairly frequently implemented practice was moving salt ( $40 \%$ ), usually to underused pasture. Less commonly implemented was spottreating underutilized pasture $(36 \%)$, most often with fertilizer, and changing supplement feeding locations (32\%), usually to underused pasture and/or away from water developments or natural water. The least commonly implemented practice was planting shrubs or trees (25\%), primarily oaks.

\section{Grazing Management}

As a result of the short course, most $(70 \%)$ of the ranchers had started and continued a rotational grazing system, the most frequent grazing management change implemented by the participants. Over half $(61 \%)$ had calculated the carrying capacity in animal unit months (AUMs) for the ranch. A similar number $(61 \%)$ had estimated pasture regrowth following grazing periods. Over half (54\%) of the respondents said that after taking a short course, they had developed an annual grazing plan. Similarly, over half $(54 \%)$ had increased livestock density to improve their pastures. Almost half $(49 \%)$ said that they had expanded their pasture numbers (with a mean increase of 3.4 pastures or paddocks). About half also had increased animal perfor- 
mance $(48 \%)$ and/or annual average stocking rates (47\%). Less than half of the ranchers had decreased annual hay purchases (43\%) and/or had initiated livestock handling practices to reduce stress (37\%).

Ranchers reported that they had changed various ways of managing their land to improve or protect natural resources on their ranches. The natural resource reported as the most improved or protected by the survey respondents was vegetative cover or residual dry matter $(25 \%)$. Vegetative cover was followed by streambanks $(20 \%)$, perennial grasses $(20 \%)$, oaks $(13 \%)$, and nonendangered terrestrial wildlife habitat $(11 \%)$. Less than $10 \%$ of the respondents said that they had improved or protected wetland habitats, endangered or rare terrestrial plant or animal habitat, and aquatic habitat for trout, steelhead, or salmon.

\section{Information Sources}

A large number (40\%) of the survey respondents reported relying on information from Cooperative Extension publications or workshops in making changes in their ranching operation. Cooperative Extension was followed by information from the California Cattleman's Association or the California Wool Growers Association (37\%). Survey respondents also relied on fellow local ranchers $(34 \%)$ or on a variety of other information sources including self-reliance, books, newsletters, journals, electronic news sources, and relatives and friends $(20 \%)$. Few respondents $(6 \%)$ relied on the Society for Range Management publications and meetings.

Over half $(52 \%)$ of the respondents said that they had done additional reading suggested in the short courses. A relatively small proportion of the participants had started practicing rangeland monitoring techniques suggested in the courses, including residual dry matter sampling (14\%) and photo point recording $(6 \%)$. A larger number of respondents had acquired information to help with their ranch planning, including ranch maps (37\%), aerial photos (36\%), and geographical information systems (GIS) print-outs $(14 \%)$. Few respondents had taken other nonCooperative Extension short courses on ranching including Holistic Resource Management (3\%) or Ranching for Profit (3\%). In contrast, almost a fifth (18\%) of the respondents had taken other Cooperative Extension short courses or activities.

\section{Training Needs}

In response to the question, "What information would you most like to learn to benefit your ranch?", over a quarter (28\%) of the respondents wrote comments indicating the need to cope with new public interests such as environmentalists and regulators. Participants also wrote of their strong interest in voluntarily initiating efficient and environmentally sound land management. Many noted that they wanted to learn more about improving natural resources, such as timber stand improvement techniques or creek bank erosion controls. More than a quarter (28\%) of the respondents also reported a need to learn more about animal health, nutrition and breeding. Other areas of future training needs which respondents mentioned were computer automation, estate planning, and marketing (16\%); forage improvement, grazing management, and weed control $(16 \%)$; and alternative enterprises (10\%).

\section{Discussion}

This study addressed the general question of what motivated California ranchers to take a Cooperative Extension ranching short course, what changes they made in their ranch operations by doing so, and whether the courses were effective in introducing or reinforcing positive ranch resource and grazing management practices. In general, short course participants were relatively small livestock operators since a previous study reported a much greater amount of land area (mean $=2,744$ hectares) owned by California ranchers (CH2M Hill 1989). Ranch economic studies have reported that the California livestock industry will increasingly rely on fewer but larger feedlots out-of-state (CH2M Hill 1989; Cothern et al. 1991). Because such constraints on the expansion of the livestock sector will increasingly favor the large corporate ranch and wealthy ranching families (Maret 1993), small livestock operators will need to be increasingly creative and efficient to maintain viable ranching operations.

Although they were gencrally small operators, the short course participants owned or leased a mean number of acres more than four times the mean number of acres of the average California farm. Studies have found that owners of large tracts of California rangeland (over 80 hectares) earn more income from selling products from their land than small landowners (Huntsinger and Fortmann 1990). The fact that less than half of the respondents who earned more than $50 \%$ of their income directly from ranching probably reflects the proportional size of their land holdings relative to larger livestock operations and smaller California farms. Similariy, enrollment rates in land conversation programs are higher for large landowners (Pacific Meridian Resources 1993). Since almost three-quarters of the respondents were enrolled in a land conservation program and the median size of their holdings was over 200 hectares, their reliance on producing products from their California rangeland is probably considerable relative to smaller landowners not represented in the survey.

From both a quantitative and qualitative evaluation of survey results, this study generally supports previous findings describing the motivations and goals of western ranch owners. Like Arizona (Smith and Marin 1972), Colorado (Bartlett et al. 1989) and Texas (Maret 1993, Rowan 1994) ranchers, the California ranchers who responded to the survey are motivated to maintain their ranches as working ranches. Both the high proportion of the participants' ranches which are family operations and the high proportion of spouses or family members who took the short course with the participants support findings that ranching is generally a cross-generational enterprise which ranchers hope to pass on to their children. Several respondents to the survey wrote that they wished to learn how to pass the ranch to the next generation.

The fact that just less than half of the respondents reported that they depend on ranching for $50 \%$ or more of their income supports similar findings for Arizona, Colorado, Texas, and Utah (Smith and Martin 1972, Bartlett et al. 1989, Maret 1993, Rowan and White 1994, Birkenfeld and Coppock 1994). Because of declining on-ranch profits, ranchers are increasingly motivated to find outside sources of income to support both their families and their ranch because they value ranching as a way of life.

A Colorado study found that ranchers without outside sources of income appear more profit-focused than ranchers with outside income opportunities (Bartlett et al. 1989). This is supported by a California study of rangeland owners which found that landowners who live on or near their land for economic reasons are more likely to actively manage rangeland resources, i.e., native oaks, than landowners who are not economically dependent on their local area (Fortmann and Huntsinger 1987). In general, the profitability of California 
ranches is restricted by population growth, changing consumer tastes, demands for alternative uses of natural resources, and loss of feedlot alternatives (CH2M Hill 1989). California ranchers are particularly limited by their competitive disadvantage of increased transportation costs to out-ofstate packinghouses and feedlots. At the same time, the large total number and value of rangeland acres and the large local demand for beef in urban areas and the Pacific Rim present California ranchers with unique opportunities provided they demonstrate management flexibility in their ranching operations (Cothern et al. 1991). This flexibility may involve diversifying on-ranch enterprises.

The importance of diversifying on-ranch enterprises for ranchers is illustrated in respondent comments to the survey question, "What would you like to learn most to benefit your ranch?" Respondents mentioned information about alternative ranching enterprises, such as fee hunting, recreational opportunities, and orchard start-up. The alternative ranching enterprises which participants had actually added or dropped to their ranching operations were remarkably diverse options. Many of these were uniquely suited to California's geographic conditions and urban markets, such as wine grape, apple, emu, and mushroom production. At the same time, the relatively small proportion of ranchers adding and/or dropping operations or indicating training needs in alternative enterprises indicates that planning for diversification and management flexibility appears to be a relatively recent strategy for many California ranchers. The challenge for all California livestock operators is one of overcoming costs, capitalizing on California's geographic location, and maintaining management flexibility given the uniquely risky California "basis" difference between the cash and futures markets and the time of delivery (Cothern et al. 1991). The high degree to which short course participants report having improved their ranch planning process indicates the importance which they attach to maintaining their ranch operation while increasing management options.

Between 1947 and 1989, California's population tripled from 10 to 30 million people. Much of this population growth has encroached on traditionally rural counties (Teitz 1990). Rapid urban growth into rural areas has brought competing local demands for land use and broad social concerns for preserving environmental quality and conserving natural resources. The survey results indicate that short course participants had improved or protected more than a tenth of their total ranch acreage and a broad range of natural resources on their ranch. Legislation and regulation in California have increasingly shifted land management decisions from the landowner to public agencies, especially when decisions relate to prescribed burning, riparian, and wetland areas; hardwood management; wildlife and fisheries habitat; and rare and endangered species. Over one-quarter of the survey respondents said that they needed to learn more about ways in which to manage their ranching operations in response to environmental concerns of public interest groups and regulatory pressures.

Most ranchers responding to the survey appeared to be relatively limited in their ability to implement ranch and grazing management changes because of their ranch resource constraints such as capital and labor, their limited use of monitoring and assessment tools, and their lack of technological knowledge. The average respondent was a relatively small livestock operator with less owned or leased land than ranchers in an earlier California study (Cothern et al. 1991). Survey comments often reflected the limitations of respondents' operation size such as the inability to hire help or buy new pasture. Despite their high rates in implementing ranch improvements, few ranchers were employing rangeland monitoring techniques such as photo points or residual dry matter sampling. A somewhat larger but still limited proportion had acquired assessment tools such as aerial photos or even GIS printouts. Many expressed interest in learning more about animal health, nutrition, and breeding. In general, the low number of respondents reporting use of technological tools and the high proportion expressing training needs in technological skills and knowledge indicate that ranchers are aware of their resource constraints and technological limitations. Future range extension efforts and ranch and grazing management short course implementation should address these needs.

\section{Conclusions}

In summary, ranchers appeared to be motivated from their needs to increase on-ranch profits through enterprise diversification, to cope with regulatory constraints, and to improve land management for future generations on a family ranch. As a result, they learned how to better use and diversify ranch resources through the Cooperative Extension ranch planning and grazing management short courses by planning ranch goals and considering alternative ranch enterprises and practices. From reviewing their goals and evaluating their ranch enterprises, many respondents reported that they had implemented ranch resource and grazing management changes. Managing ranch operations and their natural resources involves land, capital, livestock, and human resources, which are all subject to dynamic social, economic, and environmental changes. Cooperative Extension range specialists and advisors try to assist ranchers in meeting the challenges posed by many of these changes. In California, a program has been developed to help ranchers improve their ranch resources while remaining profitable. The results of this study indicate that ranchers not only need outreach efforts from applied field research but new technological and social tools to maintain family ranching, cope with environmental regulations, and diversify ranching enterprises.

\section{Literature Cited}

Bartlett, E.T., R.G. Taylor, J.R. McKean, and J.C. Hof. 1989. Motivation of Colorado ranchers with federal grazing allotments. J. Range Manage. 42:454-456.

Birkenfeld, A. H. and D. L. Coppock. 1994. Adoption of range innovations in Utah, I: Influence of system, personal, and innovation attributes. Abstr. 1994 Ann. Meet. Soc.Range Manage. Colorado Springs, Colo.

Burstein, L. and H.E. Freeman. 1985. Perspectives on data collection in evaluations, p. 15-32. In: L. Burstein, H.E. Freeman, and P.H. Rossi (eds.), Collecting evaluation data: Problems and solutions. Sage Publications, Beverly Hills, Calif. 
CH2M Hill. 1989. Final report California livestock industry economic model. Calif. Dept. Forest. and Fire Protection, Sacramento, Calif.

Cothern, J. et al. 1991. Maintaining the competitive edge in California's beef industry. Agr. Issues Cent., Univ. of Calif., Davis, Calif.

Dillman, D. A. 1978. Mail and telephone surveys: The total design method. John Wiley and Sons, New York, N.Y.

Ewing, R.A., R.N. Tuazon, N. Tosta, L. Huntsinger, R. Marose, K. Nielson, R. Motroni, and S. Turan. 1988. California's forests and rangelands: Growing conflict over changing uses. Forest. and Range. Res. Planning, Calif. Dept. Forest. and Fire Protection, Sacramento, Calif.

Fortmann, L. and L. Huntsinger. 1987. Managing California's oak woodlands: A sociological study, p. 379-384. In: T.R. Plumb and N.H. Pillsbury (eds.), Proceedings of the symposium on multipleuse management of California's hardwood resources. Pacific S.W. For. Range Exp. Sta. Gen. Tech. Rep. PSIV-100. Berkeley, Calif.

George, M. (ed.). 1990. Ranch planning and analysis short course. Ranch Res. Manage. Proj., Div. of Agr. and Nat. Res., Univ. of Calif., Davis, Calif.

George, M. and F.L. Bell (eds.). 1990. Grazing management short course. Ranch Res. Manage. Proj., Div. of Agr. and Nat. Res., Univ. of Calif., Davis, Calif.
Huntsinger, L. and L.P. Fortmann. 1990. California's privately owned oak woodlands: Owners, use, and management. J. Range Manage. 43: 147-152.

Maret, E. 1993. Women of the range: Women's roles in the Texas beef cattle industry. Texas A\&M Univ. Press, College Station, Tex.

Pacific Meridian Resources. 1993. Protecting critical hardwood resources with downer conservation incentive techniques. Calif. Dept. Forest. and Fire Protection, Sacramento, Calif.

Rowan, R.C. 1994. Are small-acreage livestock producers real ranchers? Rangelands 16: p. 161-166.

Rowan, R.C. and L.D. White. 1994. Regional differences among Texas rangeland operators. J. Range. Manage. 47: 338-343.

Smith, A. H. and W.E. Martin. 1972. Socioeconomic behavior of cattle ranchers, with implications for rural community development in the West. Amer. J. Agr. Econ. 52: p. 217-225.

Sokolow, A.D. 1989. Preserving agricultural land in California: A short history of the Williamson Act. Williamson Act Study Group Rep., Agr. Issues Cent., Univ. of Calif. Davis, Calif.

Teitz, M. B. 1990. California growth: Hard questions, few answers, p. 35-74. In: J.J. Kirlin and D.R. Winkler (eds.), California policy choices, vol. 6. School of Pub. Admin., Univ. of So. Calif., Los Angeles, Calif. 